\title{
An Absence of Modesty: the Male/Female Dichotomy in Modesty
}

\section{Blaise}

\section{Laura Crossley}

\begin{abstract}
This article examines the figure of Modesty Blaise as an action heroine in the canon of British espionage texts. It argues that the character and her stories offer multiple, liminal spaces for investigating and challenging ideas about gender, nation and class. It also addresses the current landscape of action-adventure films at a time when there are increased calls for more female-centric vehicles and gender-blind casting. While the gender politics of the Modesty Blaise franchise make for fascinating analysis, they are also played out against a backdrop of global politics. This can be seen in the first of the novels - simply entitled Modesty Blaise from 1965 - and to some extent in Joseph Losey's loose adaptation of the text in 1966. Modesty's employment by the British secret service coincides with the dismantling of the British Empire. The negotiation of gender identity that is a recurring theme in the stories intersects with the post-imperial, post-colonial concerns that dominated geopolitics at the time the original texts were released.
\end{abstract}

Keywords: Espionage, Modesty Blaise, Peter O’Donnell, British National Identity, post-Imperialism

\section{Introduction}

On the 21 May 2016, the actress Gillian Anderson retweeted a fan-made poster that depicted her as the next Bond. Anderson paid tribute to the anonymous creator and captioned the 
image: 'It's Bond, Jane Bond'. The image itself is arresting, with Anderson looking coolly beautiful against a backdrop of the famous Bond gun-barrel shot; it was retweeted over 14,000 times and liked more than double that amount. Within days, both social and mainstream media were debating the merits of a female Bond in general and Anderson in particular. The debate over who should play the next Bond is one that comes around roughly once a decade, and has been particularly prominent as the Daniel Craig era draws to a close. What is more notable this time around is that there has been a greater emphasis on calls for diversity and an enthusiastic advocating of candidates who break the traditional mould: Idris Elba has long been a fan favourite to take over the role. But alongside the calls for colourblind casting are also the calls for gender-blind casting. The idea of a female character of the same abilities and stature as James Bond is a compelling one and so 'Jane Bond' has been seized upon by fans, theorists and commentators alike. But there have been some voices of dissent. The Telegraph journalist Tim Stanley (2016) argues that,

The tag line on the Fleming paperbacks read: “James Bond: The man every man wants to be and every woman wants between her sheets”. He’s Lancelot, Siegfried, Mike Hammer. He's a man. You could turn him into a woman but it would be an entirely different film cycle. And I suspect no one would go to see it. (Stanley 2016)

Rather than commenting on the character or social mores of a text, as much gender-blind casting does, the thesis here is that a female Bond would be little more than a gimmick and detract from the character's mythology, rather than add to it. The solution to this is put forward by Catherine Shoard writing in the Guardian in May 2016: instead of simply 'transferring unreconstructed attributes from one sex to another' we should look for new and original heroines. 
And that is where this article comes in: if we want a female action heroine who is powerful, capable, independent, intelligent, comes with a rounded and fascinating back-story, and whose men folk are largely defined in relation to her and not the other way around, then we already have her. And have had her since 1963. She is a multicultural, multilingual personality with a media presence that spans film, television, radio, novels and comic-strips. Her name is Modesty Blaise. The aims of this article are threefold: to provide an overview of the Modesty Blaise oeuvre; to explore some of the liminal spaces that Modesty occupies; and to question why, despite her longevity and the richness of the source material, there has not been a sustained cinema franchise. This may, in part, be due to the critical and commercial failure of the 1966 Joseph Losey film, which remains the only big-screen adaptation of the stories. The recent increase in films centring on female action stars, however, indicates a potentially more positive reception for an independent female operative.

Modesty Blaise first appeared in May 1963 in a comic strip written by Peter O’Donnell and drawn, initially, by Jim Holdaway. The final strip was published in July 2002, and apart from the comic strip, there have been numerous incarnations across multiple media. December 2012 brought a dramatisation of the novel A Taste for Death to the Woman's Hour radio drama strand: the daily 15 minute series starred the British-Cypriot actress Daphne Alexander in the lead. This was followed the next year by an adaptation of the first, eponymous Modesty Blaise novel, and an adaptation of the seventh novel, The Silver Mistress, was broadcast in February 2017.

There are big names associated with Modesty in her various appearances: the Joseph Losey film, which is peculiar by any standards, does at least have its pleasures in the forms of Monica Vitti as Modesty, Terence Stamp as her right-hand man Willie Garvin and a silverbewigged Dirk Bogarde as the villain, Gabriel. This is a film that attains levels of camp that makes the Eurovision song contest look relatively restrained. Her status as an icon is apparent 
in other iconic pop-culture texts: if you look carefully at Pulp Fiction (US, Tarantino, 1994), you can catch Vincent Vega reading a copy of Modesty Blaise; Quentin Tarantino has (apparently) long been interested in making a Modesty Blaise film and in 2004 acted as a producer for a direct-to-DVD 'origins' film called My Name is Modesty. And yet, in many ways, Modesty Blaise is the spy who is not there.

\section{An Absence of Modesty}

If we look through the canon of espionage it is a notably male-dominated arena, with the majority of critical discussion revolving around Bond, George Smiley, Harry Palmer and their male creators - Ian Fleming, John Le Carré, Len Deighton. When women in the spy world are discussed, the focus is almost exclusively on Bond Girls and the high-kicking ladies of The Avengers (TV, 1961-9). Despite her longevity, her popularity and, quite frankly, her kick-ass-ness, Modesty Blaise rarely gets a mention. She is present in the academic canon, but largely on the fringes and it is often the Losey film more than Modesty herself which is the subject of the discussion. Rosie White's influential book, Violent Femmes (2007), is one of the few works that takes an extended look at Modesty Blaise and her world. Articles by Colin Gardner (2009) and Robbie Goh (1999) provide sustained discussions and analysis of Modesty in a variety of socio-political contexts, but these focused examinations are the exception rather than the rule. There are fleeting mentions of the film as one of the many pop-art, sub-Bond films that appeared in the 1960s. She is noticeably absent as even a passing mention as cultural context in Saints and Avengers: British Adventure Series of the 1960s (Chapman 2002) and is an even odder absence in British Comics: A Cultural History (Chapman 2011). Rosie White identifies how Modesty herself is often described - or dismissed: 
Most critics tend to write Modesty Blaise off as an ersatz female Bond. In The Lady Investigates: Women Detectives and Spies in Fiction (Craig and Cadogan 1981), for example, she is dismissed as 'a sexual object’. (White 2007 :69)

This view of Modesty Blaise as simply being a poor imitation of James Bond, and a female one at that, is ironic, perhaps, considering the growing number of female action heroes and the gathering momentum behind female actors being cast in iconic, traditionally male roles such as Doctor Who. ${ }^{1}$ However, this is still looking at defining a female re-working of a character in relation to the male original. A character who is conceived from the outset as female brings her own set of discourses and this is clearly identifiable around Modesty. What is also notable in the character is highlighted by White - sets of contradictions that both raise and elide binaristic notions (ibid.). Contradiction and duality is central to much of the (albeit limited) writing on Modesty Blaise in critical terms. Colin Gardner identifies the multiplicity of hybrid positions in the 1966 Joseph Losey film, largely linked to the input of the film's scriptwriter, Evan Jones; Robbie Goh positions the character within a complex system of representational practices centring on national identity and race. From her origins as a nameless orphan in a displaced persons camp after World War Two to her acquisition of British citizenship through a marriage of convenience, Modesty's status is frequently ambiguous and she signally lacks the solid foundations of class, family and nationhood that define many of the British intelligence officers who come before her. The sense of Modesty as classless and self-made, does, potentially, resonate with the era of her inception: the 1960s, with its Cold War tensions and shifting social barriers.

Modesty Blaise, from her inception, is far more rounded and nuanced than simply being a spoof, female Bond figure. There are, admittedly, similarities, between Fleming’s original canon and Peter O’Donnell's creation. The novels that O’Donnell developed from his own comics are straight-up action adventures and, as with Bond, frequently send Modesty to 
exotic destinations and almost invariably include larger-than-life villains and the sort of gruesome henchmen that even Bond himself might blanch at (a pair of murderous Siamese Twins in Sabre Tooth [1966]; a well-muscled hermaphrodite in the original Modesty Blaise [1965]). There is also an emphasis on the sort of luxuries that characterise much of the Bond canon. Modesty’s various properties - from her London penthouse to her villa in Tangier - are described in detail, as are her jewels and expensive clothes. The novels are, arguably, better written than Fleming's and were critically praised, even by his fellow authors. Kinglsey Amis (also one of Fleming's admirers) declared Modesty and Willie to be 'one of the great partnerships in crime fiction, bearing comparison with that of Sherlock Holmes and Dr Watson' (Anon. 2010). A letter written by Amis to O’Donnell, and replicated on the site Modesty Blaise Ltd (2013), runs:

I just wanted to thank you and congratulate you for having written the Modesty Blaise books. They are endlessly fascinating. I read them all for the second time recently when laid low by a very depressing bout of 'flu, and I'm sure they did quite as much as the doctor did to put me on my feet again. My most grateful good wishes.

Yours sincerely

Kingsley Amis

PS My wife is an equally enthusiastic fan.

There are arguments, especially when looking at the comic strips, that Modesty can be seen purely as a fantasy figure (although, so is Bond) for male readers. However, as an independently wealthy young woman who is both a successful entrepreneur and sexually empowered, she chimes with the emerging modern girl of the 1960s and potentially even 'might be said to prefigure Thatcher herself: the self-made powerful woman who determines policy and dictates this to men' (Goh 1999: 42). It is possibly this aspect of independence and 
empowerment that make Modesty so appealing to a female audience and while the novels frequently dwell on her physicality (and the comic strips can be almost fetishistic in their depiction of her ${ }^{2}$ ), the emphasis is placed on her capabilities as an operative.

The novels also situate her more firmly in the tradition of espionage, specifically British espionage. And while many recognisable tropes remain in situ - exotic locations, irredeemably evil villains, threats to British national security, sex and glamour - O’Donnell creates a far more sophisticated structure of relationships and alliances that blur received notions of British character and heroism, as well as post-Imperial and post-colonial power balances.

\section{A Very British Heroism}

The dominant mode of British spy fiction was established early on, alongside the emergence of the real world intelligence services (Trotter 1991: 30). The heroes of early spy fictions, such as John Buchan's Richard Hannay, are often amateurs and always 'gentlemen', and notions of race and class are inherent to the positioning of the British hero. They share all of the perceived traits of duty, stoicism, courage and perseverance as the lauded Imperial heroes of the late nineteeth and early twentieth centuries, such as Gordon, Clive, Lawrence and Havelock. Films in the style of Sanders of the River (Korda, 1936) maintain these codes and, as Jeffry Richards argues, the films offer a justification of the British empire, not through politics or economics, but through valorising the supposedly superior British national character which is partially defined as working to preserve 'law, order and justice for love of those qualities’ (Richards 1997: 40).

These codes of behaviour, and maintenance of the ideals that reaffirm British superiority, are then imported into the spy canon. Crucially, there is the implicit 
understanding that the British spy is male and that he comes exclusively from the ranks of the privileged upper classes:

[T]here can be no fear in the mind of the reader that they will be tempted by the lures of city vice or socialism, or be other than deeply loyal to class, country, and king. (Stafford 1981: 503)

The concept of Britishness is, therefore, constructed as the unchanging central component of the defenders of British interests. To be foreign is immediately to be suspect and to be working class immediately raises the possibility of socialist leanings. To be female is not even countenanced.

The villains against whom the heroes are ranged are then defined by their 'otherness' and a clear structure of binary oppositions is set up that works to maintain the superiority of the British agent:

The Villain is born in an ethnic area that stretches from Central Europe to the Slav countries and to the Mediterranean basin: usually he is of mixed blood and his origins are complex and obscure. (Eco 1979: 151)

Significantly, this complexity and obscurity of the villain are traits shared by Modesty Blaise herself: she is marked as different not only by her sex, but also her ethnicity. Within the traditional world of British spy fiction she is, from the start, a problematic figure, with both her femininity and her foreignness marking her as unreliable: more an exotic and duplicitous Mata Hari than a stoically British Edith Cavell. James Bond, the character with whom Modesty is most frequently compared, is the Son of Empire, bearing all of the traits of the traditional British hero: despite the transformations and soft reboots that come with each 
iteration of the cinematic Bond, he is never fully loosed from his origins in the privileged officer class. In many ways, Bond is a deeply conservative figure and he offers a fantasy image of the incorruptible and unstoppable British hero, even as real-world British power is slowly eroded. Despite the superficial trappings of sex, violence and glamour, there is actually very little similarity between the characters of Bond and Modesty Blaise and the worlds in which they operate.

So, where does Modesty Blaise fit? Where does she come from? Her creator, Peter O’Donnell, had been working on comic strips (adventure) and serials for women’s magazines (romance, but with a streak of adventure) when he was asked to create a new strip:

I had been intrigued by the idea of bringing these two genres together by creating a woman who, though fully feminine, would be as good in combat and action as any man, if not better. ('Girl Walking: The Real Modesty Blaise’ n.d.)

The result was Modesty. Her back-story is as convoluted as any Bond villain's and was inspired by a young girl O’Donnell saw at the end of the Second World War. She is a child of war, possibly from somewhere in the Balkans; her real name and her actual age are lost and unknown to everyone, including Modesty. A one-time leader of a global criminal network (no drugs or prostitution, though - and she always eschewed dealing in any secrets detrimental to British national security) who retired when she had made enough money to be independently wealthy for the rest of her life. Modesty Blaise is the name that she gave herself. In many ways, she is her own creation. Her acquired wealth allows her entry into the international jet-set of the 1960s and while media within the stories may refer to her erroneously as an English socialite, her exoticism is foregrounded. As Goh notes she is depicted: 
([I]n the novels as well as the cartoon illustrations) with a dark sensuousness that may be Slavic or Mediterranean, but is definitely not the fair English beauty of, say, Fleming's Mary Goodnight. (1999: 32)

The novels also emphasise the slight accent in her spoken English that serves as a reminder of her inherent 'foreign-ness'. In conventional spy fiction, these factors would all relegate Modesty to secondary status. Bond girls exist purely because Bond does and even The Avengers women are usually described as sidekicks and are always seen in relation to John Steed. But Modesty is the focus; there are no stories without her.

Her constant companion, however, is a man - Willie Garvin. And ordinarily, Willie would be the central hero: as a character, he is fully equipped to play the role and with a back-story as convoluted as Modesty's own, he could easily be the next soul-searching yet rugged hero that any actor could desire. Willie's (at best) working class origins also mark him out as 'Other' in the world of British spy fiction. The late 1950s saw the emergence of literature that gave a voice to working class characters and this would develop as a dominant trend in the 1960s as the upper-class heroes and role-models of old were replaced actors, musicians, models and photographers whose working-class backgrounds became cool. Before then, however, the working classes were largely marginalised and excluded in representational practice.

\section{A Touch of Class}

With the release of the film version of Doctor No in 1962, the cinematic representation of the British spy was still dominated by the image of the officer-class gentleman and this is replicated in the character of John Steed in The Avengers. Towards the end of the 1960s, that image would undergo significant challenges: first by the release of The Ipcress File in 1965 
and on TV by the introduction of Callan (1967-72) - a series that was conceived as a realistic riposte to the fantastical glamour of The Avengers. The nameless protagonist of Deighton's original novel, The Ipcress File (1962), is a grammar school and red brick-university educated son of the north; the working-class, cockney Harry Palmer rescued from military prison by the (naturally) upper-class Colonel Ross is an invention of the film. But if schooling is always a signifier of social status, then the descending order is clear: James Bond (public school), Harry Palmer (grammar school), David Callan (state school), with Willie Garvin coming in at the bottom: Approved School. As with Modesty, Willie is 'othered' through his class and criminal background and, arguably, is placed even further outside of accepted societal norms in that he is second-in-command to a woman. However, it is made clear canonically that he is happy to be so: Modesty's skills and abilities move her beyond any questions of gender roles.

Some of the contradictions that Rosie White identifies are apparent here: Willie is a man's man and becomes something of the yardstick, as it were, against which to measure Modesty. Willie is routinely shown to have a physical prowess and ability with constructing and using weapons that make him a superior example of the warrior male; however, he is also independently-minded and over the course of the first novel, spy-boss Sir Gerald Tarrant is delighted to discover that Willie is also well-read, well-informed, knowledgeable about wine and has decided opinions on the respective merits of Mozart and Shostakovich. Willie Garvin is a paragon and yet Modesty stands above even him: she is better than a man. Yet, she still has to remain, in O'Donnell's words, 'fully feminine'. The latter attribute is immediately apparent in the Losey film, where Monica Vitti's glamour is at the forefront. When we are first introduced to the film version of Modesty, she is stretched languorously in bed in a fully automated apartment; the ensuing theme song concludes that she is 'the perfect mistress of her part/and the perfect mistress too'. The film's final image of her is of a romanticised, 
Orientalist exoticism, dressed in the flowing Arab robes in true Lawrence of Arabia-style, but with the added eye make-up of Cleopatra. This in itself is a duality: the other women in the Arab encampment are in black, with their faces covered, whereas Modesty's face is visible and the garb she is wearing is a man's. In between, the martial capabilities that are a defining characteristic of Modesty in the novels and comic-strips are not particularly evident. Similarly, the film also reduces the Blaise/Garvin relationship to a romantic one: they reflect on the possibilities of their partnership, unexpectedly, in song and later decide to get married.

However, the film retains Modesty’s outsider status and much of the action hinges on her ability to transcend and blur many of the traditional binaristic structures. The more recent radio versions present a more straightforward telling of the stories, although the central casting does make some departures from the earlier versions: while they retain Modesty's back-story (and the casting of British-Cypriot Daphne Alexander is the closest to Modesty's own ethnic origins), Alexander's Received Pronunciation delivery align this incarnation of the character with the upper-class, English privilege of Cathy Gale and Emma Peel. As the first broadcast adaptation was of the fourth novel, A Taste for Death, there is no mention of Modesty's origins and so as an entry point, it overlooks much of the detail that makes Modesty such a satisfying character and a newcomer to the stories would be left wholly unaware of Modesty's origins. What is retained, from the outset, is Modesty's prowess as a warrior. The series opens with what appears to be a physical fight between Modesty and an unknown male; it soon becomes apparent that it is a sparring session between Modesty and her current boyfriend, Steve Collier, who explains, weakly, to Sir Gerald Tarrant, that as Willie Garvin is away, Modesty insists on practising on him. Modesty's counter is that she was attempting to teach him how to disarm a knife-wielding attacker. Throughout the series, and the two that follow, Modesty is simply presented as the most capable person involved in the mission, with little to no comments made about her sex. Similarly, Willie's working class 
background is not something that is a factor in how he is received by the majority of characters and his innate intelligence, despite his lack of formal education, challenges traditional structures that link privilege with intellect.

Robbie Goh's article on the novels of the Modesty canon careful unpicks the liberalhumanist ethos that imbues O’Donnell's work and emphasis is placed on Modesty herself as a nexus: her network of friends and colleagues are drawn across racial, class and gender lines, and status is bestowed not as a birthright, but as something earned. The people who are the beneficiaries of her help and friendship frequently share Modesty's own levels of openminded tolerance. Even the notion of the 'gentleman' is somewhat reconceptualised: Sir Gerald Tarrant bemoans figures of the establishment who are born with money and privilege but without the 'instincts of a gentleman' (O’Donnell 1967: 97). The radio adaptation of $A$ Taste for Death also sees Sir Gerald questioning his own status as a gentleman: when Modesty tells him that her Canadian houseguest, Dinah Pilgrim, will be delighted to take tea with a 'courtly old English gentleman,' he asks her to allow Dinah to keep her illusions; 'Don’t tell her,' he says, 'what a ruthless bastard I am'.

No longer, therefore, does class automatically determine merit and worth: Willie Garvin is a gentleman, the members of the ruling classes who frequently obstruct Tarrant and Modesty frequently are not. This is a marked deviation from the heroic figure that David Stafford identifies, who is almost invariably, 'of the right social class and with the correct education carrying out his duty to his country regardless of the cost or sacrifice’ (1981: 503). Without these traditional signifiers of class and education, Modesty and Willie are disruptive, almost subversive figures and yet - those contradictions again - the ease with which they transcend and blur boundaries, coupled with their loyalty to the British nation state, make them ideal agents. 


\section{Modesty on Screen}

Joseph Losey’s film takes these re-workings and develops the attitudes into a far more satiric view of the old boy networks that characterise much of early spy fiction. (Admittedly, we still see these networks, intact, in many contemporary espionage tales - the recent adaptation of Le Carré's The Night Manager (2016) being a case in point). Modesty’s alignment with the 'other' then functions as throwing a spotlight onto the 'centre' and the result is far from flattering for the traditional structures of power and privilege. An early scene in the film is the briefing of Modesty by Sir Gerald Tarrant (Harry Andrews) and the Home Secretary (Alexander Knox) about the situation at the heart of the story: a consignment of diamonds being given by the British government to Sheik Abu Tahir, the leader of a fictitious Middle Eastern state, Massara, in exchange for safeguarding valuable oil concessions. The diamonds are to be the object of a heist carried out by Dirk Bogarde’s villainous Gabriel, and Modesty is needed to prevent the whole débacle. The briefing itself takes place in the sort of woodpanelled room usually seen in gentlemen's clubs, or the office of the Bernard Lee-era $\mathrm{M}$ in the Bond series. While the projector shows a series of generic images denoting the Arab world, the Minister undertakes to explain the situation to Modesty and his disconnect is immediately apparent: he mistakes Modesty's name and continues to make a series of mistakes that are corrected by either Tarrant or Modesty. Throughout, Modesty keeps her back to the screen and it is soon made obvious that she knows far more about the people and places involved than either of the two men.

Minister: That is the Kingdom of Cassara

Tarrant: Massara, sir.

Minister: Scarcely large enough to be on the map.

Modesty: About the size of England and Wales. 
Minister: Turned everything over to the natives ten ...

Tarrant: Fifteen.

Minister: Fifteen years ago. Since then, of course, the place has gone to seed ... The revolution led by the Sheik’s first cousin ...

Modesty: Second cousin; a man who claims to be a trade unionist.

Tarrant: Right-wing, of course. Ah, that's the Sheik himself. A retired cut-throat called Abu Tahir. I know him well.

Modesty: Do you?

The attitude of superiority of the British Establishment displayed by Tarrant and even more so by the Minister is, perhaps, not an entirely appropriate attitude given the slow collapse of the British Empire that was all but complete by the time that the film was released. The Minister, self-congratulatory about the perceived failings of the independent Arab state, reflects an idea that the Imperial project had been not just beneficial and benevolent, but necessary to the democratic and economic development of countries beyond Europe. His evident stance is undermined by the playing of the scene itself, as it carries the underlying implications that it is the 'centre' that is now obsolete and the 'other', in the person of Modesty, that is in the ascendant. This rather patronising attitude towards Modesty and the former colonies is carried through to the meeting with Sheik Abu Tahir himself.

As she is escorted through a grand London hotel, Modesty is given a lesson on how to conduct herself with the Sheik and his entourage:

Tarrant: I don't know how much you know of Arab etiquette, but the thing to avoid above all is familiarity. These chaps are as proud as Lucifer and a woman amongst Muslims must be particularly careful. 
Before Modesty and Tarrant even enter the suite, a man in Arab dress gets out of the car that is parked in the hotel corridor and engages Modesty in a finger-gun fight while they chant 'Wham, bam, thank you, Ma'am!' in a call-and-response exchange. He then proceeds to sweep Modesty into an embrace, lifting her off her feet - and finishes by informing Tarrant that, 'It is the Muslims who must be careful of Modesty Blaise'. The interior of the suite conforms to every expected cliché and stereotype of the newly rich Arab in the West: the rooms are overflowing with fashionable clothes, black-clad women, stoves, motorbikes and various radios playing Western pop and traditional Arab music simultaneously. To his assembled entourage, the Sheik announces, 'He is here! My son, Modesty'. Adopted by the Sheik whilst still a refugee, Modesty was deemed to be too fierce to be a daughter, and so is made a son and taught how to fight. On the one hand, it speaks of received ideas of masculinity and femininity and what constitute the defining traits; yet there is also an acceptance of gender fluidity, at least around Modesty and it is noteworthy that this comes from the 'uncivilised' Sheik, and not from the more 'superior' British. It is in Abu Tahir's company that we see Modesty at the close of the film - her white and gold robes the fitting attire for the son of a Sheik.

It could be argued that the depiction of Arab culture in the film is essentialist with its emphasis on an exoticised and romanticised 'Orientalism'; however, in a film that takes highcamp and satire as its performance register, the exaggerated depiction of the Sheik does not seem out of place. The mix of art film and populist genre piece results in a tonally uneven film that offers up even more fluidity and instability around character than the source material. It is, perhaps, for these reasons, that in terms of discussing Modesty Blaise within the academic canon, Losey's film arguably attracts the majority of the (admittedly slim) writings. 
Gardner's focus on the 1966 Modesty Blaise in relation to two other cold war-era thrillers, The Damned (Losey, 1962) and Funeral in Berlin (Hamilton, 1968), explore the common thematic concerns of the trio, which are all scripted by the Jamaican poet, playwright and screenwriter, Evan Jones. Jones' initial script for Modesty Blaise used the character as 'a vehicle for some well pointed ideological critique of the macho and amoral cliche's of the espionage genre as well as cold war politics as a whole' (Gardner 2006: 181). The taut, narratively concise script that Jones delivered was then largely re-written by Losey and the whole enterprise transformed into a spectacle of baroque camp. When it was presented at Cannes, Losey claimed that he wanted to make the film that would end all of the James Bond-esque films. Apparently, however, he had only seen one half of one Bond film (Crowther 1966). The elaborate aesthetics and the 'avalanche of visual puns' (Gardner 2008: 181) that dominate the film's stylistics sit awkwardly with a story that, at heart, is a straightup action adventure. This becomes more obvious when Monica Vitti as Modesty is required to engage in the sort of hand-to-hand combat in which Modesty is meant to be a specialist.

This is exemplified in the sequence when secret agent - and Modesty's former lover Paul Hagen (Michael Craig) returns home to find that the notorious Modesty Blaise is both in his living room and also the woman he had previously known in Paris as Jaqueline. The brief physical fight between them looks awkward in both blocking and execution: it lacks either the panache of the highly stylised choreographed fight scenes of The Avengers or the more naturalistic urgency of sequences such as the train-board encounter between Bond and Red Grant in From Russia With Love (Young, 1963). Far from being a match between two professionals, the audience is treated to some uncomfortable grappling that is enhanced by grunts and heavy breathing that were clearly added in post-production. It is possible that the approach is deliberate and that Losey's intent is to mock the sort of fetishised engagements mentioned in the previous examples; but as the film veers so wildly between parody, satire 
and conventional thriller, it is almost impossible to construct a satisfactory spectatorial framework. What the film does set up is a series of doubles and substitutions that offer a far more complex, reflexive reading than the quasi-surrealist visuals initially indicate. Admittedly, the underlying logic is not made manifest and the reasons behind some of the doubling-up is bewildering: why, for example, Clive Revill plays both Sheik Abu Tahir and the villain's henchman McWhirter, when there are no discernible narrative or thematic links between the two, is frustratingly unclear.

Alan Burton's (2018) overview of the reception of the film in the 1960s highlights the film's critical and commercial failure, which largely centred on the perceived impenetrability of the film's narrative and aesthetics. One of the aspects that is most frequently noted is the switching of Monica Vitti's clothing and hair - from blonde to brunette and back again often within the same scene and without any apparent cause. The O’Donnell graphic novels and film strips also exist within the diegetic world: Willie Garvin has a Jim Holdaway drawing of Modesty on his wall and the scene where Paul Hagen meets Modesty opens with her glancing at a pile of magazines that includes a Modesty Blaise graphic novel and an article that seems to include a feature on Monica Vitti playing Modesty. The scene escalates through the fight and leads to the somewhat theatrical revealing of Vitti recognisably styled as Modesty from the comic strips. Vitti starts the scene in a black dress and with her blonde hair loose; it ends with her emerging from an array of oversized potted plants dressed in a black cat-suit, fully armed and her now dark hair piled on her head, in a pose that mimics the cover of the graphic novel and the poster on Willie's wall. There are numerous possible readings that can brought to this; Gardner (2006) points to it as being evidence of the instability of the feminine construct (although, this overlooks the fact that both Bogarde's and Stamp’s characters undergo similar inexplicable alterations). 
Another possible interpretation links back to Goh's view of Modesty - and Willie - as transcending binaristc oppositions and moving across barriers of class, race and gender. The film makes this manifest through the playful, knowing visual style and also draws attention to the fact that, in fiction at least, the ideal agent is adaptable and almost invisible due to their ability to fit in with any company and any occasion. This complexity and the liminal spaces that Modesty inhabits are not unique to the film and are central to understanding the character.

\section{Looking Out for a Hero(ine)}

Modesty's gender and her sexuality have always been a component of the material, but one that is knowingly deployed. Despite the fact that she has been, as Rosie White identifies, dismissed as a sexual object, the novels position Modesty as sexually active and sexually desiring, with her wants being the determining factor and not the other way around. She enjoys sex on her own terms and there is a refreshing lack of judgement around Modesty's approach to her sexual relationships. This is extended to Modesty's approach to nudity as something that is natural and she is free from any embarrassment (it is the reason her mentor, Lob, in the refugee camps began jokingly calling her Modesty). Her retention of both that name and her own attitudes underline the idea that there is nothing inherently immodest about nudity, but that the sexualisation of it is a societal construct. It is a construct, however, that Modesty is happy to exploit: one of her trademark moves is 'The Nailer' whereby she strips to the waist before walking bare-breasted into a roomful of heavies. Their stunned reaction earns her enough time to beat them up. Although, as nudity becomes mainstream, it doesn't always stun quite enough as she and Willie ruefully acknowledge in a sequence from the strip ‘The Reluctant Chaperone’ (1975): 
Willie: Funny... But last time you worked that dodge a couple of years back you got a five second freeze - tonight it was only three.

Modesty: Must be all these sex films, Willie... They're making The Nailer obsolete.

Willie: We could appeal to the unions, maybe?

The gender and socio-political contexts of the original strips and novels have certainly shifted, yet this is a character whose final adventure was published in the Standard as late as 2003. With a growing chorus demanding more equality in terms of representation and a clear demonstration that female action heroes are not only tolerated by wished for, it seems strange that a figure as compelling as Modesty Blaise should be so overlooked. The failure of the Losey film in itself is not the cause: by the time of its release in 1966 it was simply one of many campy Bond-esque spoofs and Modesty's popularity in comic strips and novelisations arguably increased in the following years. In many ways, the oversaturated market for spy films by the late 1960s may have been another contributing factor to why there was reluctance to develop another franchise; even Harry Palmer only had another two outings with Billion Dollar Brain (1967) proving unpopular with both critics and audiences. There is also, however, the very real possibility that an action thriller stripped of parody and irony and focusing on a female protagonist was simply not something that was seen as being a viable cinematic commodity; without a protecting layer of satire and stylized aesthetics, Modesty was, perhaps, too provocative and unruly a figure to be contained by the cinema screen.

However, the fact is that Modesty is not the only sidelined figure in contemporary media, and many choices around which character is foregrounded, particularly in cinema, have more to do with commerce and the perceived tastes of audiences, rather than a reflection of current trends. A 2016 interview with director Shane Black (Ryan 2016) revealed that in 
2013’s Iron Man 3, the supervillain should have been female - Rebecca Hall’s Maya Hansen. It was deemed, however, that no-one would buy the action figure if it was female; Hall's role was greatly reduced and the positon of the main villain fell to Guy Pearce's Aldrich Killian. That was, as Black is at pains to point out, a decision taken at the corporate level and there has been something of a shift since the restructuring of the Disney/Marvel enterprise removed Marvel Studios from the guidance of Marvel Entertainment CEO Ike Perlmutter. Joanna Robinson's article for Vanity Fair (2015) highlights the inherent sexism that seems to dominate much of the corporate structures of media conglomerates:

This largely antiquated, gender-divided approach to merchandising would explain, for example, why Disney initially had "no plans for Leia products at the Disney store” or why they sold a women’s “I Need a Hero" shirt and a men’s "Be a Hero” shirt, or why Zoe Saldana's character Gamora was missing from the Guardians of the Galaxy merchandise last year ... [I]t seems pretty clear that Disney doesn’t think boys are interested in female heroes and, even worse, that little girls don't care about action heroes at all. So what, exactly, do they think blockbuster characters like Katniss, Maleficent, and Princess Elsa are?

Fans of the Marvel Cinematic Universe - male and female alike - are still calling for the standalone Black Widow movie, but there is yet to be confirmation of production; although, the forthcoming Jennifer Lawrence vehicle Red Sparrow (Lawrence, 2018) looks greatly like a Black Widow origins movie in all but name. 2017 saw the long-awaited arrival of DC's Wonder Woman, a project helmed by director Patty Jenkins which was the most critically and commercially successful addition to the DC Extended Universe; also released was the Cold War-set Atomic Blonde (Leitch, 2017), which built on Charlize Theron's emerging power as an action icon after her performance in Mad Max: Fury Road (Miller, 2015). The future of 
female-led action films does seem to be more viable than it was even five years ago, yet many of these stories still revolve around heightened stylistic, fetishised sexuality and ultraviolence. The appetite, however, for female-centric stories, is demonstrably there and even more than that is the existence of female characters who fulfil all the contemporary requirements for psychological complexity and character-driven narrative. We do not need a re-write of James Bond into a female version of the role; rather, what we need is lot more Modesty.

\section{References}

Anderson, Gillian (2016) 'It’s Bond. Jane Bond. Thanks for all the votes! (And sorry, don't know who made poster but I love it!)’ [Twitter] 21 May, available https://twitter.com/gilliana/status/734145694055976960?lang=en, accessed 22/03/2017.

Anon (2010), 'Peter O’Donnell’, The Telegraph [online], available http://www.telegraph.co.uk/news/obituaries/culture-obituaries/booksobituaries/7682764/Peter-ODonnell.html, accessed 24/03/2017.

Burton, Alan (2018), Looking Glass Wars: Spies on British Screens since 1960, Wilmington, Delaware: Vernon Press.

Chapman, James (2002), Saints and Avengers: British Adventure Series of the 1960s, London: I. B. Tauris.

— (2011), British Comics: A Cultural History, London: Reaktion Books.

Crowther, Bosley (1966), 'Gaudy Modesty Blaise, Girl Secret Agent', The New York Times [online], available 
http://www.nytimes.com/movie/review?res=9F04E3DE163AEF34BC4952DFBE668 38D679EDE, accessed 25/03/2017.

Eco, Umberto (1979), The Role of the Reader: Explorations in the Semiotics of Texts,

Bloomington: Indiana University Press.

Forshaw, Barry (2012), British Crime Film: Subverting the Social Order, London: Palgrave Macmillan.

Gardner, Colin (2006), ‘From Mimicry to Mockery: Cold War Hybridity in Evan Jones’s The Damned, Modesty Blaise and Funeral in Berlin', Media History, 12: 2, pp. 177-191.

'Girl Walking: The Real Modesty Blaise’ (n.d.), in Crime Time [online], available http://www.crimetime.co.uk/features/modestyblaise.php, accessed 20/03/2017.

Goh, Robbie (1999), 'Peter O’Donnell, Race Relations and National Identity: The Dynamics of Representation in 1960s and 1970s Britain’, Journal of Popular Culture, 32: 4, pp. $29-43$.

'Modesty Blaise Ltd’ (2013), Letter from Kingsley Amis to Peter O’Donnell [online] available http://www.modestyblaiseltd.com/Peter-O-Donnell, accessed 25/03/2016.

O’Donnell, Peter (1967), I, Lucifer, New York: Mysterious.

— (1975), 'The Reluctant Chaperone’, The London Evening Standard, 26/03/197514/08/1975.

Richards, Jeffrey (1997), Film and British National Identity: From Dickens to Dad's Army, Manchester: Manchester University Press.

Robinson, Joanna (2015), 'Why Is Scarlett Johansson Missing from the Avengers Merchandise?’, Vanity Fair [online], available http://www.vanityfair.com/hollywood/2015/04/black-widow-avengers-sexist, accessed 03/04/2017. 
Ryan, Mike (2016), ‘Shane Black On The Nice Guys, Mel Gibson, And Why A Female Iron Man 3 Villain’s Gender Changed', Uproxx [online], available http://uproxx.com/movies/shane-black-the-nice-guys-iron-man-3/, accessed 3/04/2017.

Shoard, Catherine (2016), 'Jane Bond is just James in a frock. We need a new heroine', The Guardian [online], available https://www.theguardian.com/commentisfree/2016/may/25/jane-bond-james-heroinegillian-anderson, accessed 22/03/2017.

Stafford, David (1981), 'Spies and Gentlemen: The Birth of the British Spy Novel, 18931914', Victorian Studies, 24: 4, pp. 489-509.

Stanley, Tim (2016), ‘The name's not Jane Bond: why 007 can never be a woman’, The Telegraph [online], http://www.telegraph.co.uk/films/2016/05/25/the-names-not-janebond-why-007-can-never-be-a-woman/, accessed 22/03/2017.

Trotter, David (1991), 'The Politics of Adventure in the Early British Spy Novel’, in Wesley K. Wark (ed.) Spy Fiction, Spy Films and Real Intelligence, Abingdon and New York: Routledge, pp. 30-54.

White, Rosie (2007) Violent Femmes, London and New York: Routledge.

Laura Crossley is a lecturer in Film Studies at Bournemouth University, with a $\mathrm{PhD}$ from the University of Manchester. Areas of interest focus on representations of British national identity in film and television, British stars and stardom and the function of nostalgia in film. She has published on the spy film and is the co-editor of Routledge Studies in Espionage and Culture. 
${ }^{1} 2017$ saw the casting of Jodie Whittaker as Doctor. Similarly, the current American adaptation of the Sherlock Holmes canon, Elementary (2012-) attracted controversy when Asian American actress Lucy Liu was cast as Joan Watson, a move that has since received both critical and popular praise due to Liu's performance.

2 This is more notable in the Enrique Badía Romero iterations, which are noticeably more voluptuous and exoticised than the original Holdaway drawings of the character. 